\title{
Improving HOTS in Biology Learning: A Supplement Book of Plant Growth and Development
}

\author{
Supriyatin*, Sri Rahayu, Rizhal Hendi Ristanto, Ilmi Zajuli Ichsan \\ Faculty of Mathematics and Natural Science, Universitas Negeri Jakarta, Indonesia
}

Received September 8, 2019; Revised November 1, 2019; Accepted November 8, 2019

Copyright $\odot 2019$ by authors, all rights reserved. Authors agree that this article remains permanently open access under the terms of the Creative Commons Attribution License 4.0 International License

\begin{abstract}
Biology learning in the 21st century requires Higher Order Thinking Skills (HOTS) especially on the topics of Plant Growth, Development, and Environment. The purpose of this study was to improve students HOTS in learning Biology using the Supplement Book of Plant Growth and Development (SB-Plant). The research method used in this study was an experiment with a sample of 56 students. The instruments used were 8 items about HOTS, which have been declared valid and reliable. The results showed that the average HOTS score of students increased significantly by using SB-Plant. The highest gain score in the third indicator (create) with an increase in gain score of 0.46 (moderate). Meanwhile the smallest increase occurred in the first indicator (analyze) with a score of 0.20 (low). The conclusion was that SB-Plant is effectively used to increase HOTS in Biology learning.
\end{abstract}

Keywords SB-Plant, HOTS, Learning, Students

\section{Introduction}

21st Century Biology learning has made learning change from teacher -center to the student -center. Students are not only asked to record everything explained by the teacher, but also actively seek various information [1-3]. The impact of this change in learning approach resulted in students also being required to have higher abilities in terms of thinking. This ability is often referred to Higher Order Thinking Skills (HOTS) which is the ability to analyze, evaluate, and create [4-6]. This ability was skills that can be trained in learning at the classroom.

In Biology learning specifically in topic growth and development of plants, students really need HOTS. This is because on this topic a lot of material is not enough just to use the ability to memorize and remember. In detail, if we want to learn about the role of internal factors such as genes and hormones in plants, it requires the ability of HOTS.
This is because the topic has many problems that are relevant to daily life and must be solved by students [7-9]. This makes HOTS important for students to learn about plant growth and development.

The problem that arises is that the ability of students HOTS is still relatively low [10,11]. Many kinds of research have revealed the profile of students HOTS in science learning [12-14]. In addition to the HOTS profile of students, many researches have been done to improve various skills to improve the quality of science learning [15-17]. Other research such as developing digital learning media and online-based learning, one of them was the development of the Supplement Book of Plant Growth and Development (SB-Plant) for high school students [18]. Supplement Book is a book that serves to explore a particular topic.

In previous research, SB-Plant has not been implemented in the classroom. SB-Plant has the potential to improve students HOTS, especially when discussing the topic Plant Growth and Development. This SB-Plant will be used in classroom and on trial effectively to improve students HOTS. Based on this, the purpose of this study was to improve students' HOTS in Biology learning using SB-Plant.

\section{Methods}

The method used in this study was one group experiment without a control group. The treatment given was Supplement Book of Plant Growth and Development (SB-Plant) products that had previously been developed [18]. This research was conducted in July-August 2019 in senior high school students. The schools used in this study were 2 schools. The sample, which was selected by simply random sampling, selected 56 students in 12th grade. The instrument used was a Higher Order Thinking Skills test consisting of 8 items given during the pre-test and post-test. The indicator of HOTS instrument used 
consists of 3 aspects, namely analyze, evaluate, and create [4]. More details can be seen in table 1 .

Table 1. Indicator of instrument

\begin{tabular}{|c|l|c|}
\hline Aspect & \multicolumn{1}{|c|}{ Indicator } & Item \\
\hline $\begin{array}{c}\text { C4 } \\
\text { (Analyze) }\end{array}$ & $\begin{array}{l}\text { Analyze the factors that cause growth and } \\
\text { development of plants }\end{array}$ & $1,2,3$, \\
\hline $\begin{array}{c}\text { C5 } \\
\text { (Evaluate) }\end{array}$ & $\begin{array}{l}\text { Criticize the role of internal and external } \\
\text { factors of plant growth and development }\end{array}$ & $4,5,6$ \\
\hline C6 (Create) & $\begin{array}{l}\text { Create simple research designs and concept } \\
\text { maps about plant growth and development }\end{array}$ & 7,8 \\
\hline
\end{tabular}

The validity test used in this study was the Pearson product-moment. Meanwhile the reliability calculation used alpha Cronbach. After the instrument was declared valid and reliable, the data was collected and presented in table. Analysis of the data used the normality and homogeneity test then proceeded with the dependent t-test using SPSS. In addition, the gain score is also calculated to see the magnitude of the average increase in each item. After calculating the gain score, the next step was to categorize the gain score according to the criteria in Table 2 .

Table 2. Category of community attitudes

\begin{tabular}{|c|c|}
\hline Gain Score & Criteria \\
\hline $\mathrm{g} \geq 0,7$ & High \\
\hline $0,7>\mathrm{g} \geq 0,3$ & Moderate \\
\hline $\mathrm{g}<0,3$ & Low \\
\hline
\end{tabular}

SB-Plant consists of 5 parts, from cover, introduction, main content, conclusion, and evaluation for students. These five parts were made because the SB-Plant was an additional book that was for advance. That was because the textbooks in schools are not as deep as those discussed at SB-Plant. The SB-Plant book was made in Indonesian language. However, a description of the SB-Plant book can be seen in table 3 .

Table 3. Part and Description of SB-Plant

\begin{tabular}{|c|c|c|}
\hline No & Part & Description \\
\hline 1 & Cover & $\begin{array}{l}\text { Cover describes a plant that experiences } \\
\text { growth and development }\end{array}$ \\
\hline 2 & Introduction & $\begin{array}{l}\text { This section explains various basic terms } \\
\text { such as the notion of growth and } \\
\text { development, and a general description of } \\
\text { the concept of growth and development }\end{array}$ \\
\hline 3 & Main content & $\begin{array}{l}\text { In the main content section, the concept of: } \\
\text { 1. Internal factors of growth and } \\
\text { development: genetics, plant hormones } \\
\text { 2. External factors of growth and } \\
\text { development: temperature, humidity, } \\
\text { acidity, nutrient content, etc. }\end{array}$ \\
\hline 4 & Conclusion & $\begin{array}{l}\text { In this section students are asked to draw } \\
\text { conclusions and evaluate and comment on } \\
\text { events related to plant growth and } \\
\text { development }\end{array}$ \\
\hline 5 & $\begin{array}{l}\text { Evaluation for } \\
\text { students }\end{array}$ & $\begin{array}{l}\text { In this section students are asked to discuss } \\
\text { and answer HOTS questions which consist } \\
\text { of the ability to analyze, evaluate and } \\
\text { create }\end{array}$ \\
\hline
\end{tabular}

Source: Supriyatin \& Ichsan [18].

\section{Result and Discussion}

The results of the study showed that all items are valid and reliable. Then the data is described in table. Data are presented pre-test post-test and gain scores. Calculation of the gain score is the difference between the test post and pre-test. More can be seen in table 4 . In Table 4 the largest increase can be seen from the gain score, which is in item 8 , while the smallest increase is in item 5. Overall it has increased in each item. Then the students HOTS score can be seen from each indicator in Table 5 .

Table 4. Students HOTS scores viewed from each item

\begin{tabular}{|c|l|c|c|c|c|}
\hline No & \multicolumn{1}{|c|}{ Item } & pre & post & gain score & category \\
\hline 1 & Analyzing the effects of auxin deficiency & 2.95 & 4.23 & 0.14 & Low \\
\hline 2 & Analyzing the effect of abscisic acid on roots, leaves, stems, fruits & 2.39 & 4.70 & 0.24 & Low \\
\hline 3 & Analyzing the effect of ethylene on fruit & 2.39 & 4.34 & 0.20 & Low \\
\hline 4 & Comments about the temperature factor for plants & 4.05 & 4.86 & 0.10 & Low \\
\hline 5 & Comments about the factor of excessive fertilizer purchase & 3.21 & 5.39 & 0.25 & Low \\
\hline 6 & Giving arguments about plant genes & 1.80 & 4.70 & 0.28 & Low \\
\hline 7 & Creating a research design about plant growth and development & 2.98 & 7.50 & 0.50 & Moderate \\
\hline 8 & Making a concept map about plant growth and development & 1.11 & 5.68 & 0.42 & Moderate \\
\hline
\end{tabular}

Table 5. Student HOTS scores viewed from each indicator

\begin{tabular}{|l|c|c|c|c|}
\hline \multicolumn{1}{|c|}{ Indicator } & Pre & Post & Gain & Category \\
\hline Analyzing the factors that cause growth and development of plants & 2.58 & 4.42 & 0.20 & Low \\
\hline $\begin{array}{l}\text { Criticizing the role of internal and external factors of plant growth and } \\
\text { development }\end{array}$ & 3.02 & 4.98 & 0.22 & Low \\
\hline $\begin{array}{l}\text { Creating simple research designs and concept maps about plant growth and } \\
\text { development }\end{array}$ & 2.04 & 6.59 & 0.46 & Moderate \\
\hline
\end{tabular}


Dependent t-test was conducted to test the significance of the difference between the pre-test and post-test scores. Significant test results showed the t-value is higher than t-table. In addition, if seen from the Sig value $<0.05$, it can be concluded that the post-test score is significantly higher than the pre-test score. This can be interpreted that SB-Plant can increase the HOTS of senior high school students.

Table 6. Dependent t-test results

\begin{tabular}{|c|c|c|c|c|}
\hline Mean & Std. Deviation & t-value & df & Sig. (2-tailed) \\
\hline 20.50 & 13.30 & 11.528 & 55 & .000 \\
\hline
\end{tabular}

Based on the results of the study it can be said that the SB-Plant is effectively used in Biology learning. That was because SB-Plant was developed with the characteristics of senior high school students who find it difficult to understand the topic. SB-Plant has several advantages such as (1) easy to understand contains (2) simply packaged (3) based on HOTS. These three advantages cause SB-Plant products to increase HOTS of senior high school students in Biology learning. As an Supplement book, SB-Plant is in accordance with its function which is to deepen students' knowledge on the topic of plant growth and development [19,20].

The first advantage is that contains are easy to understand. Most textbooks used in schools often contain languages that are difficult to understand. Textbook often uses Latin terms and is too rigid, unlike the SB-Plant which uses simple and communicative language. In the discussion of auxin, ethylene and abscisic acid, it is explained simply using language that is easier to understand. The use of this language was important because good learning media must be communicative [21-23].

The second advantage is simply packaged. Layout of SB-Plant is simple without using much writing. Besides that the number of pages presented in SB-Plant is only 27 pages. Then the distance between the lines also uses large spaces, so students can easily read them. These pages will make it easier for students to get important points from the concepts to be described in the SB-Plant. The sentences are also not long and straight to the point. This makes it easy for students to understand because the information conveyed will be more informative [24-26].

The third advantage is SB-Plant was a HOTS based book. This can be seen in the students' activity section that contains instructions for students to discuss. In addition, students are asked to analyze and evaluate the phenomena in their environment related to plant growth and development. In addition, the topic presented in learning to use SB-Plant is material that requires HOTS capability, for example regarding the impact of fertilizer use in plants. Students will be trained to analyze the problem and then evaluate the effects of excessive fertilizer use. After that student are expected to create innovation to solve these problems. The ability of HOTS is expected to be used by students to solve problems regarding the growth and development of plants that they encounter every day [27-29].

The increase caused by the use of SB-Plant is due to these three advantages. When seen in table 3 , it is clear that the biggest increase occurred in item 7 , designing experiments on plant growth and development. This showed that SB-Plant stimulates students to be able to make a research design [30,31]. Then when seen in table 4 , the biggest increase was also found in the third indicator which is about the aspect of creation. This indicates a positive thing considering the score from the aspect of creation that is relatively low in pre-test. Meanwhile, if we see the smallest increase occurring in the first indicator regarding analyzing the factors inhibiting plant growth and development. This indicates that this book has not generated much data that can make students analysis power increase significant [32,33].

As for implementation of SB-Plant in schools, there are still some shortcomings that must be noted. One of them is the availability of time in the use of SB-Plant. Biology learning at the senior high school level, teachers often skip the discussion about growth, development, and plant environment in detail. This is because the teacher considers that the growth and development of plants are something that students can already understand though students may not be able to understand it well. This must be overcome because students must understand a topic from basic concept [34-36].

In using this SB-Plant, the teacher can combine it with learning models. Teacher must use learning models that prioritize problem-solving, because there are very suitable for use in learning combine with SB-Plant to improve HOTS [8,9,37-39]. Problem-based learning model, for example, the teacher can first give a case relating to the growth and development of plants such as the low number of fruits on a mango tree. After that, to solve the case, students are asked to learn the concept through SB-Plant. Then after learning about the growth, development, and environment of plants, students are asked to provide solutions to the problem of the small number of fruits in the mango tree.

\section{Conclusions}

Based on the results of the study it can be concluded that the HOTS score of students has increased. This proves that SB-Plant is effectively used in learning Biology and can improve HOTS. That is because SB-Plant has the advantages of which (1) contains easy to understand language (2) is simply packaged (3) is based on HOTS. Implementation of SB-Plant can combine with Problem-Based Learning (PBL) to solve the problem about plant growth and development. 


\section{Acknowledgements}

Thank you for Faculty of Mathematics and Natural Science, Universitas Negeri Jakarta for funding this research in 2019. Thank you to all the respondents who have been participated in this research.

\section{REFERENCES}

[1] Camacho, D. J., \& Legare, J. M. (2015). Opportunities to Create Active Learning Techniques in the Classroom. Journal of Instructional Research, 4, 38-45.

[2] Derevenskaia, O. (2014). Active Learning Methods in Environmental Education of Students. Procedia - Social and Behavioral Sciences, 131, 101-104. https://doi.org/10.101 6/j.sbspro.2014.04.086

[3] Sukiniarti. (2016). Improving Science Pedagogic Quality in Elementary School Using Process Skill Approach Can Motivate Student to Be Active in Learning. Journal of Education and Practice, 7(5), 150-157.

[4] Anderson, L. W., Krathwohl, D. R., Airiasian, W., Cruikshank, K. A., Mayer, R. E., \& Pintrich, P. R. (2001). A taxonomy for learning, teaching and assessing: A revision of Bloom's Taxonomy of educational outcomes: Complete edition. New York: Longman.

[5] Zohar, A., \& Alboher Agmon, V. (2018). Raising test scores vs. teaching higher order thinking (HOT): senior science teachers' views on how several concurrent policies affect classroom practices. Research in Science and Technological Education, 36(2), 243-260. https://doi.org/1 $0.1080 / 02635143.2017 .1395332$

[6] Murphy, C., Bianchi, L., McCullagh, J., \& Kerr, K. (2013). Scaling up higher order thinking skills and personal capabilities in primary science: Theory-into-policy-intopractice. Thinking Skills and Creativity, 10, 173-188. https://doi.org/10.1016/j.tsc.2013.06.005

[7] Kartikaningtyas, V., Kusmayadi, T. A., \& Riyadi, R. (2018). The effect of brain based learning with contextual approach viewed from adversity quotient. Journal of Physics: Conference Series, 1022.

[8] Gündüz, A. Y., Alemdağ, E., Yaşar, S., \& Erdem, M. (2016). Design of a Problem-Based Online Learning Environment and Evaluation of its Effectiveness. The Turkish Online Journal of Educational Technology, 15(3), 49-57. https://d oi.org/10.1017/CBO9781107415324.004

[9] Khoiriyah, A. J., \& Husamah, H. (2018). Problem-based learning: Creative thinking skills, problem-solving skills, and learning outcome of seventh grade students. JPBI (Jurnal Pendidikan Biologi Indonesia), 4(2), 151-160. https://doi.org/10.22219/jpbi.v4i2.5804

[10] Hwang, G.-J., Lai, C.-L., Liang, J.-C., Chu, H.-C., \& Tsai, C.-C. (2018). A long-term experiment to investigate the relationships between high school students' perceptions of mobile learning and peer interaction and higher-order thinking tendencies. Educational Technology Research and Development, 66(1), 75-93. https://doi.org/10.1007/s1142

\section{$3-017-9540-3$}

[11] Hugerat, M., \& Kortam, N. (2014). Improving higher order thinking skills among freshmen by teaching science through inquiry. Eurasia Journal of Mathematics, Science and Technology Education, 10(5), 447-454. https://doi.org/10. 12973/eurasia.2014.1107a

[12] Garcia, L. C. (2015). Environmental Science Issues for Higher- Order Thinking Skills (HOTS) Development: A Case Study in the Philippines. In Biology Education and Research in a Changing Planet (pp. 45-54). https://doi.org/ 10.1007/978-981-287-524-2

[13] Aisyah, A., Salehuddin, K., Aman, I., Yasin, R. ., \& Mimiko, N. (2018). Eliciting Elements of Higher Order Thinking Skills in the Higher Secondary Examination Question Structure in Japan and Malaysia Aznur. In Proceedings of the Regional Conference on Science, Technology and Social Sciences (RCSTSS 2016) (pp. 455-464). Springer Singapore. https://doi.org/10.1007/978-981-13-0074-5

[14] Yee, M. H., Yunos, J. M., Othman, W., Hassan, R., Tee, T. K., \& Mohamad, M. M. (2015). Disparity of Learning Styles and Higher Order Thinking Skills among Technical Students. Procedia - Social and Behavioral Sciences, 204(November 2014), 143-152. https://doi.org/10.1016/j.s bspro.2015.08.127

[15] Şener, N., Türk, C., \& Taş, E. (2015). Improving Science Attitude and Creative Thinking through Science Education Project: A Design, Implementation and Assessment. Journal of Education and Training Studies, 3(4), 57-67. https://doi.org/10.11114/jets.v3i4.771

[16] Fisher-Maltese, C., \& Zimmerman, T. D. (2015). A garden-based approach to teaching life science produces shifts in students' attitudes toward the environment. International Journal of Environmental and Science Education, 10(1), 51-66. https://doi.org/10.12973/ijese.201 $5.230 \mathrm{a}$

[17] Vieira, R. M., \& Tenreiro-Vieira, C. (2016). Fostering Scientific Literacy and Critical Thinking in Elementary Science Education. International Journal of Science and Mathematics Education, 14(4), 659-680. https://doi.org/10 $.1007 / \mathrm{s} 10763-014-9605-2$

[18] Supriyatin, S., \& Ichsan, I. Z. (2018). Pengayaan Materi Pertumbuhan dan Perkembangan Tumbuhan Melalui Pengembangan Bahan Ajar. Jurnal Biotek, 6(2), 13-24. https://doi.org/https://doi.org/10.24252/jb.v6i2.6468

[19] Cheung, A. C. K., \& Slavin, R. E. (2013). The effectiveness of educational technology applications for enhancing mathematics achievement in K-12 classrooms: A meta-analysis. Educational Research Review, 9, 88-113. https://doi.org/10.1016/j.edurev.2013.01.001

[20] Yavich, R., \& Starichenko, B. (2017). Design of Education Methods in a Virtual Environment. Journal of Education and Training Studies, 5(9), 176. https://doi.org/10.11114/je ts.v5i9.2613

[21] Yusop, F. D., \& Sumari, M. (2013). The Use of Social Media Technologies among Malaysian Youth. Procedia - Social and Behavioral Sciences, 103, 1204-1209.https://doi.org/1 0.1016/j.sbspro.2013.10.448

[22] Blaschke, L. M. (2014). Using Social Media to Engage and 
Develop The Online Learner in Self-Determined Learning. Research in Learning Technology, 22(1), 1-23.

[23] Yusuf, M. M., Amin, M., \& Nugrahaningsih. (2017). Developing of Instructional Media-Based Animation Video on Enzyme and Metabolism Material. Jurnal Pendidikan Biologi Indonesia, 3(3), 254-257.

[24] Miarsyah, M., Rusdi, R., Aryani, N. D., \& Ichsan, I. Z. (2019). MEBA: Development Android-based Ecosystem Module for Senior High School Students. Indian Journal of Public Health Research and Development, 10(8), 21142118. https://doi.org/10.5958/0976-5506.2019.02168.5

[25] Chang, J. H., Chiu, P. S., \& Huang, Y. M. (2018). A sharing mind map-oriented approach to enhance collaborative mobile learning with digital archiving systems. International Review of Research in Open and Distributed Learning, 19(1), 1-24.

[26] Sigit, D. V., Azrai, E. P., Heryanti, E., Ichsan, I. Z., Jajomi, Y. P., \& Fadrikal, R. (2019). Development Green Consumerism E-Book for Undergraduate Students (GC-EBUS) as Learning Media in Environmental Learning. Indian Journal of Public Health Research and Development, 10(8), 2026-2031.

https://doi.org/10.5958/0976-5506.2019.02152.1

[27] Husamah, H., Fatmawati, D., \& Setyawan, D. (2018). OIDDE Learning Model: Improving Higher Order Thinking Skills of Biology Teacher Candidates. International Journal of Instruction, 11(2), 249-264.

[28] Smith, V. D., \& Darvas, J. W. (2017). Encouraging Student Autonomy through Higher Order Thinking Skills. Journal of Instructional Research, 6, 29-34.

[29] Vidergor, H. E. (2018). Effectiveness of the multidimensional curriculum model in developing higher-order thinking skills in elementary and secondary students. Curriculum Journal, 29(1), 95-115. https://doi.or $\mathrm{g} / 10.1080 / 09585176.2017 .1318771$

[30] Ritter, S. M., \& Mostert, N. (2017). Enhancement of Creative Thinking Skills Using a Cognitive-Based Creativity Training. Journal of Cognitive Enhancement, 1(3), 243-253. https://doi.org/10.1007/s41465-016-0002-3

[31] Wojciehowski, M., \& Ernst, J. (2018). Creative by Nature : Investigating the Impact of Nature Preschools on Young Children's Creative Thinking. International Journal of Early Childhood Environmental Education, 6(1), 3-20.

[32] Djamahar, R., Ristanto, R. H., Sartono, N., Ichsan, I. Z., Darmawan, E., \& Muhlisin, A. (2019). Empowering Student's Metacognitive Skill through Cirsa Learning. Journal of Physics: Conference Series, 1227, 12034. https://doi.org/10.1088/1742-6596/1227/1/012034

[33] Xia, B. S. (2017). An In-Depth Analysis of Teaching Themes and the Quality of Teaching in Higher Education: Evidence from the Programming Education Environments. International Journal of Teaching and Learning in Higher Education, 29(2), 245-254.

[34] Suhendar, S., \& Wahyuni, A. (2018). Achievement and response of students at favorite junior high schools in sukabumi on trends in international mathematics and science study (timss) questions. Biosfer: Jurnal Pendidikan Biologi, 11(2), 126-133. https://doi.org/10.21009/biosferjp b.v11n2.126-133

[35] Pratama, A. T. (2018). Improving metacognitive skills using problem based learning (pbl) at natural science of primary school in deli serdang, indonesia. Biosfer: Jurnal Pendidikan Biologi, 11(2), 101-107. https://doi.org/https:// doi.org/10.21009/biosferjpb.v11n2.101-107

[36] Fauzi, A., \& Fariantika, A. (2018). Courses perceived difficult by undergraduate students majoring in biology. Biosfer: Jurnal Pendidikan Biologi, 11(2), 78-89. https://d oi.org/10.21009/biosferjpb.v1 $\ln 2.78-89$

[37] Barber, W., King, S., \& Buchanan, S. (2015). Problem based learning and authentic assessment in digital pedagogy: Embracing the role of collaborative communities. Electronic Journal of E-Learning, 13(2), 5967.https://doi.org/10.1002/tl.7401

[38] Ichsan, I. Z., Sigit, D. V., Miarsyah, M., Ali, A., Arif, W. P., \& Prayitno, T. A. (2019). HOTS-AEP: Higher order thinking skills from elementary to master students in environmental learning. European Journal of Educational Research, 8(4), 935-942. https://doi.org/10.12973/eu-jer.8.4.935

[39] Permana, F. H., \& Chamisijatin, L. (2019). Project-based learning through edmodo: improving critical thinking and histology concepts. Biosfer: Jurnal Pendidikan Biologi, 12(1), 58-69. https://doi.org/10.21009/biosferjpb.v12n1.58-69 